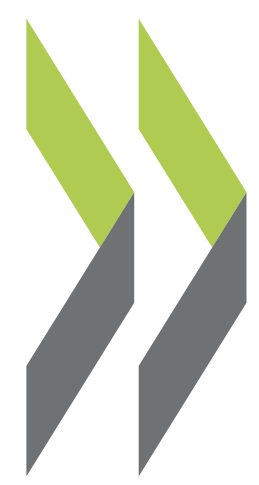

OECD Working Papers on International Investment 2014/02

\section{Investment Treaties \\ and Shareholder Claims}

for Reflective Loss: Insights from Advanced Systems of Corporate Law
David Gaukrodger

https://dx.doi.org/10.1787/5jz0xvgngmr3-en 


\section{OECD WORKING PAPERS ON INTERNATIONAL INVESTMENT}

The international investment working paper series - including policies and trends and the broader implications of multinational enterprise - is designed to make available to a wide readership selected studies by the OECD Investment Committee, OECD Investment Division staff, or by outside consultants working on OECD Investment Committee projects.

The papers are generally available only in their original language English or French with a summary in the other if available.

Comment on the series is welcome, and should be sent to investment@oecd.org or the Investment Division, OECD, 2, rue André Pascal, 75775 PARIS CEDEX 16, France.

OECD WORKING PAPERS ON INTERNATIONAL INVESTMENT

are published on www.oecd.org/daf/inv/investment-policy/working-papers.htm.

OECD Working Papers should not be reported as representing the official views of the OECD or of its member countries. The opinions expressed and arguments employed are those of the authors.

Working Papers describe preliminary results or research in progress by the author(s) and are published to stimulate discussion on a broad range of issues on which the OECD works. Comments on Working Papers are welcomed, and may be sent to investment@oecd.org or the Investment Division, Directorate for Financial and Enterprise Affairs, OECD, 2 rue André-Pascal, 75775 Paris Cedex 16, France.

This document and any map included herein are without prejudice to the status of or sovereignty over any territory, to the delimitation of international frontiers and boundaries and to the name of any territory, city or area.

The statistical data for Israel are supplied by and under the responsibility of the relevant Israeli authorities. The use of such data by the OECD is without prejudice to the status of the Golan Heights, East Jerusalem and Israeli settlements in the West Bank under the terms of international law.

\section{(C) OECD 2014}

Applications for permission to reproduce or translate all or part of this material should be made to: OECD Publishing, rights@oecd.org or by fax 33145249930. 


\title{
Investment Treaties and Shareholder Claims for Reflective Loss: Insights from Advanced Systems of Corporate Law
}

\author{
by \\ David Gaukrodger, Senior Legal Advisor, OECD Investment Division
}

\begin{abstract}
Corporate law in advanced domestic legal systems on the one hand, and typical treaties for the protection of foreign investment on the other hand, treat claims for damages by company shareholders differently. Advanced domestic systems generally bar shareholders from claiming for reflective loss - loss that arises from injury to "their" company (such as a decline in the value of shares). The claim for the loss belongs to the injured company and not to its shareholders. In contrast, shareholder claims for reflective loss have been widely permitted under typical investment treaties over the last 10 years. Ongoing OECD-hosted inter-governmental dialogue on investment law is considering whether there are policy reasons justifying the different approaches to shareholder claims for reflective loss.

This paper examines shareholder claims for reflective loss under investment treaties in light of comparative analysis of advanced systems of corporate law. The paper considers the impact of allowing shareholder claims for reflective loss on key characteristics of the business corporation. The paper also explores possible responses by different categories of investors to the availability of shareholder claims for reflective loss under investment treaties.
\end{abstract}

Approved by Adrian Blundell-Wignall, Director, OECD Directorate for Financial and Enterprise Affairs

JEL Classification: F21, F23, F53, F55, F63, G32, G34, G38, K23, K33, K41.

Key words: shareholders; stockholders; shareholder claims; shareholder rights; shareholder remedies; stockholder remedies; reflective loss; reflective injury; derivative action; derivative loss; derivative injury; consistency; consistency of arbitral decisions; judicial economy; settlement; corporate law; company law; creditors; creditors' rights; loan covenants; business corporations; separate legal personality; entity shielding; limited liability; board of directors; agency costs; transferability of shares; investor-state dispute settlement; international arbitration; arbitrators; international economic law; comparative law; domestic impact of investment law; international arbitration; investment arbitration; foreign investment; international investment; international investment law; access to justice; level playing field; competitive neutrality; treaty shopping; international investment agreements; investment treaties; bilateral investment treaties 


\section{TABLE OF CONTENTS}

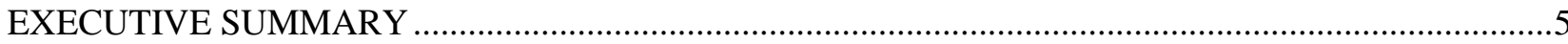

A. INTRODUCTION

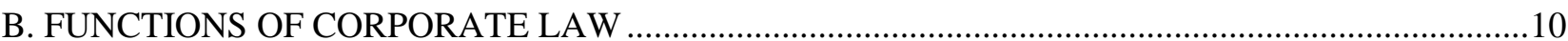

1. Defining recognised organisational forms possessing key attributes …............................................10

2. Reducing the costs of organising business through the corporate form by

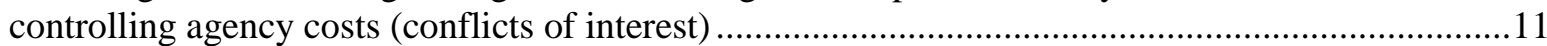

3. Permitting the corporation to serve efficiently as a distinct contracting party ................................11

C. CHARACTERISTIC FEATURES OF THE BUSINESS CORPORATION IN ADVANCED

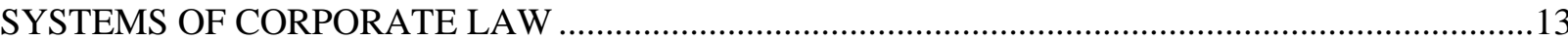

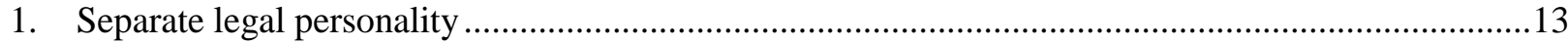

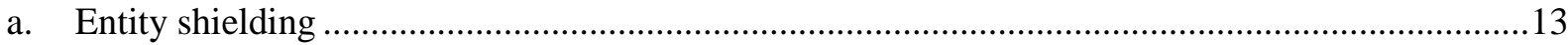

b. The capacity of the company to sue and be sued in its own name ................................................15

c. Defining who can bind the company: the question of authority over the separate legal entity .......15

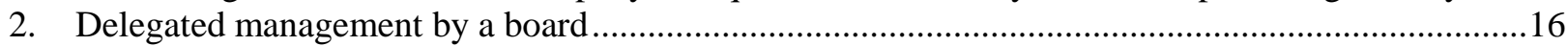

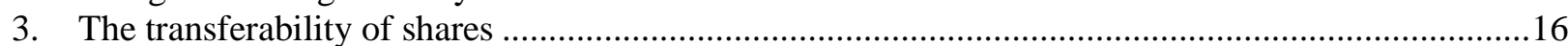

D. CONSIDERATION OF CORPORATE LAW MAY SUGGEST ADDITIONAL POLICY ISSUES RELATING TO SHAREHOLDER CLAIMS FOR REFLECTIVE LOSS IN ISDS ................18

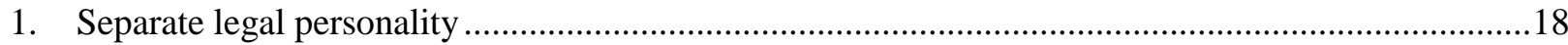

a. Policies relating to the impact of shareholder claims for reflective loss on entity shielding ..........18

b. Impact on the capacity of the company to sue and be sued in its own name .................................21

c. Corporate law rules creating the company's separate legal personality, which are generally considered to be value-enhancing, may not be replicable by contract ............................22

2. Impact of shareholder claims for reflective loss on centralised and delegated

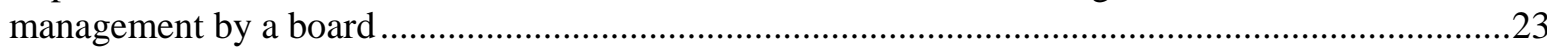

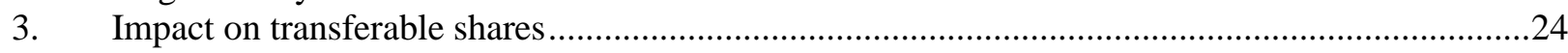

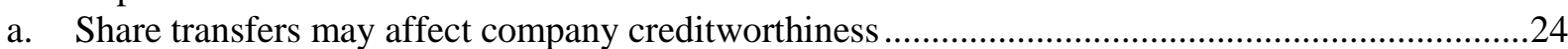

b. Transfers of shares and transfers or retention of rights to bring SRL ............................................24

E. POSSIBLE RESPONSES BY INVESTORS TO THE AVAILABILITY OF SHAREHOLDER

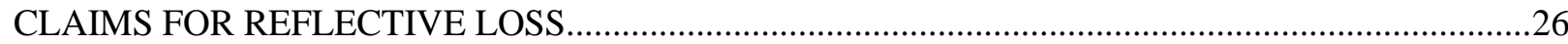

1. Increased investment by Category I (likely claimant) shareholders ..............................................26

2. Potential responses by creditors to the availability of shareholder claims for reflective loss.............26

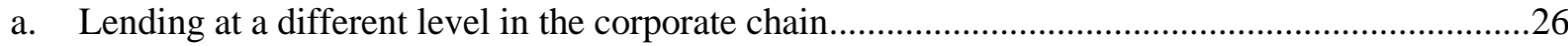

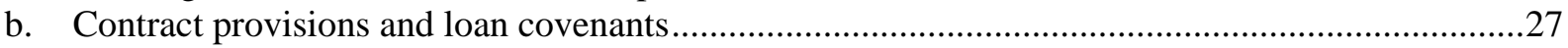

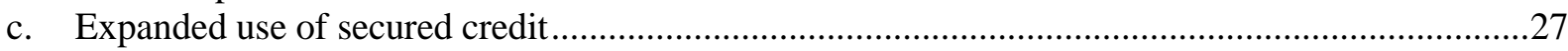

d. Rely on ISDS arbitrators taking account of creditor interests in shareholder claim cases..............28

e. Rely on shareholder reputational interests and commercial considerations....................................29

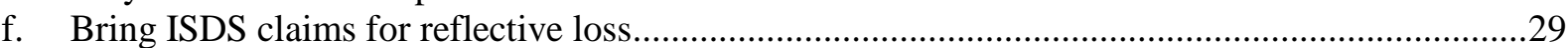

g. Increase the price and/or decrease the availability of credit for foreign investment ......................29

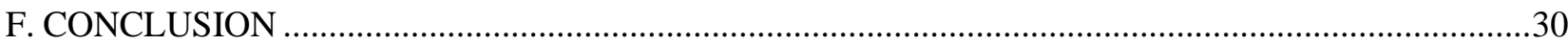

Box 1. Risks to creditors and tax authorities from assets being moved around shareholder ownership chains. 


\section{EXECUTIVE SUMMARY}

At the March 2013 Freedom of Investment (FOI) Roundtable hosted by the OECD, participants recognised that advanced systems of corporate law generally bar individual shareholder claims for reflective loss. ' (Shareholders' reflective loss is incurred as a result of injury to "their" company, typically a loss in value of the shares; it is generally contrasted with direct injury to shareholder rights, such as interference with shareholder voting rights.) Only the directly-injured company can recover the loss. The Roundtable also noted that, in investor-state dispute settlement (ISDS) claims brought under typical bilateral investment treaties (BITs), arbitrators have consistently permitted shareholders to claim for reflective loss. Outcomes for shareholders thus differ under advanced systems of corporate law and typical BITs.

The Roundtable considered the policy basis for the general prohibition on individual shareholder claims for reflective loss (SRL) in advanced national systems and its relevance to ISDS, with a particular focus on issues of consistency. The Roundtable noted that further and broader consideration of corporate law was appropriate before seeking to draw analogies between national law and investment law or trying to determine which has the better approach to SRL. This paper accordingly considers SRL in a broader context of purposes of advanced systems of corporate law. The preliminary analysis here of broader corporate law principles relevant to SRL is primarily derived from the work of a major comparative corporate law project involving leading scholars from several countries (Germany, Italy, Japan, Switzerland, United Kingdom, United States). ${ }^{2}$

The paper first outlines three important functions of corporate law: (i) providing business enterprises with easily-usable and recognisable legal forms that have known attributes; (ii) reducing the costs of organising business through the corporate form; and (iii) permitting companies to serve efficiently as distinct contracting parties. The distinctive features of the business corporation - the most widely used organisational form for large-scale enterprise in all advanced corporate law jurisdictions - are described, including in particular its separate legal personality, the limited liability of its shareholders, the transferability of its shares and its delegated management through a board.

Separate legal personality refers to a number of key attributes of the corporation that allow it to serve as an efficient contracting party. In addition to the ability of the company to sue and be sued in its own name and rules regarding who has authority to act in the name of the company, these include "entity shielding" - protection of the company's assets from its shareholders and the personal creditors of those shareholders.

Entity shielding is achieved through rules that give creditors priority over shareholders for access to company assets and that provide liquidation protection to the entity by preventing shareholders from withdrawing their share of firm assets at will. Entity shielding permits the firm to make contractual and

1 See FOI Roundtable 18, Summary of discussion, p. 5 (March 2013). The background paper for the March 2013 discussion was David Gaukrodger, Investment Treaties as Corporate Law: Shareholder Claims and Issues of Consistency, OECD Working Paper on Investment 2013/3. Further information on the Roundtable is available on the OECD website.

2 Reinier Kraakman et al., The Anatomy of Corporate Law (2d ed. 2009). 
other commitments that are credible because they are bonded by company assets; facilitates and lowers the cost of the company's access to credit; and, together with limited liability, greatly simplifies both company and individual shareholder insolvency. Together, owner shielding (limited liability) and entity shielding set up two separate pools of assets: business assets are pledged as security to business creditors, while the personal assets of shareholders are reserved for those shareholders' personal creditors. Corporate law scholars have suggested that the corporate law rules creating the company's separate legal personality in advanced jurisdictions are value-enhancing for the company and cannot be replicated by contract.

For creditors (and non-claiming shareholders), the availability of SRL in investor-state dispute settlement (ISDS) may mean that regulatory risk is compounded by (i) liquidation risk because SRL may prevent the company from reconstituting its assets following the government injury; (ii) priority risk because it may be unclear whether ISDS arbitrators will be able to prioritise creditor claims adequately; and (iii) interference with governance of the company by the board because each shareholder covered by an investment treaty allowing for SRL can unilaterally decide to bring a SRL at any time, based on its own view of government action, with uncertain consequences for the company. SRL also introduces variations in the rights of shareholders which may raise policy issues relating to the transferability of shares.

The paper concludes by considering possible responses by investors to the availability of SRL in ISDS. Some corporate constituencies and in particular covered shareholders with significant investments benefit from exceptional remedies through SRL in ISDS and can be expected to increase their investments. Others face new risks. The paper preliminarily considers how market participants, and in particular creditors, may seek to respond to the new rules in ISDS. Creditor reactions may range widely to include modified lending practices, demanding higher prices for credit or attempts to bring reflective loss claims as creditors. Creditor losses may be concentrated among smaller unsophisticated creditors. 


\section{A. INTRODUCTION}

At its discussion in March 2013, the OECD-hosted Freedom of Investment (FOI) Roundtable recognised that advanced systems of corporate law generally prohibit shareholder claims for reflective loss (SRL). ${ }^{4}$ (Shareholders' reflective loss is incurred as a result of injury to "their" company, typically a loss in value of the shares; it is generally contrasted with direct injury to shareholder rights, such as interference with shareholder voting rights.) Only the directly-injured company can recover the loss. The Roundtable also noted that, in claims brought under typical bilateral investment treaties (BITs), many arbitral tribunals have found that shareholders covered by BITs are entitled to recover for reflective loss. Outcomes for shareholders thus differ under advanced systems of corporate law and typical BITs. ${ }^{5}$

The Roundtable considered the policy reasons relating to consistency for the general prohibition on SRL in advanced national systems of corporate law, as identified by courts and corporate law scholars. The Roundtable noted that analysis of advanced systems of domestic corporate law was useful to identify policy consequences of allowing shareholder claims for reflective loss. Preliminary discussions also suggested that governments have taken different approaches to SRL in their treaties and may have different views about the costs and benefits of SRL in investor-state dispute settlement (ISDS).

The Preliminary Framework paper discussed in March 2013 was primarily focused on the dispute resolution context in which SRL occur and addressed the impact of SRL in ISDS on the dispute resolution system and on respondent governments. ${ }^{6}$ The Roundtable noted that further consideration of the purposes of domestic corporate law and investment law was appropriate before seeking to draw analogies between national law and investment law or trying to determine which has the better approach to SRL. ${ }^{7}$ This background paper places the discussion of SRL in a broader context of the purposes of advanced systems of corporate law in order to assist governments and others with this process. ${ }^{8}$ This has several objectives.

3 This paper does not necessarily reflect the views of the OECD or of the governments that participate in the FOI Roundtable, and it should not be construed as prejudging ongoing or future negotiations or disputes pertaining to international investment agreements.

The following economies are invited to participate in the Roundtable: Argentina, Australia, Austria, Belgium, Brazil, Bulgaria, Canada, Chile, China, Colombia, Costa Rica, Czech Republic, Denmark, Egypt, Estonia, Finland, France, Germany, Greece, Hungary, Iceland, India, Indonesia, Ireland, Israel, Italy, Japan, Jordan, Korea, Latvia, Lithuania, Luxembourg, Malaysia, Mexico, Morocco, Netherlands, New Zealand, Norway, Peru, Poland, Portugal, Romania, Russian Federation, Saudi Arabia, Slovakia, Slovenia, South Africa, Spain, Sweden, Switzerland, Tunisia, Turkey, United Kingdom, United States and the European Union. Participation typically varies somewhat depending on the issues being discussed.

See FOI Roundtable 18, Summary of discussion, p. 5 (March 2013).

Id.

References herein to the "Preliminary Framework" refer to David Gaukrodger, Investment Treaties as Corporate Law: Shareholder Claims and Issues of Consistency, OECD Working Paper on Investment 2013/3. That paper provides a preliminary framework for policy analysis of shareholder claims and consistency in ISDS.

FOI Roundtable 18, Summary of discussion, pp. 8-9.

As in the Preliminary Framework, for purposes of policy discussion only, some general meanings are given to certain terms herein. References to shareholders refer generally to shareholders covered by an investment treaty; where clarification is needed, covered and non-covered shareholders are distinguished. References to shareholders also generally include both direct and indirect shareholders. 
First, in areas where investment policy is affecting corporate law principles, a broader understanding of corporate law purposes and functions may help governments to integrate them with their investment policy goals; this may assist governments in better aligning the purposes of the two bodies of law (or better integrating them where their purposes may conflict). Second, an understanding of how the SRL rule fits into the broader structure of corporate law should help facilitate discussions by investment policy makers with corporate law experts, both at the Roundtable and in their home jurisdictions. Third, a broader review of relevant corporate law goals and purposes may suggest some additional policy considerations of potential relevance for investment policy on shareholder claims beyond those identified in the Preliminary Framework and in the Roundtable discussion in March.

As noted in the Preliminary Framework, there has been little academic or case law consideration of the impact of the ISDS rules on SRL on companies or corporate finance. This relative lack of attention to the interface between ISDS and corporate law appears to characterise both commentary about investment law and research into company law.

The preliminary analysis here of ISDS in the light of broader corporate law principles relevant to SRL primarily relies on an analytical framework derived from the work of a major comparative corporate law project involving leading scholars from many advanced corporate law jurisdictions. The project, which has involved over a decade of work, is reflected in The Anatomy of Corporate Law. ${ }^{9}$ The paper also draws on a leading treatise on Corporate Finance and on other national law sources and commentary. ${ }^{10}$

The focus here is on the business corporation, the most widely used corporate form for large-scale enterprise and investment in all advanced corporate law jurisdictions. Focusing initially on the most popular type of organisation for large scale investment makes sense for several reasons. The rules on SRL in most ISDS cases have typically been formulated in general terms with regard to shareholders rather than being restricted to shareholders of particular types of companies. ${ }^{11}$ Nor do treaties generally single out

References to the "company" refer to the company in which the shareholder owns shares (directly or indirectly). References to the "operating company" generally refer to the company that is active and that incurs the direct loss due to government misconduct. Domestic company refers to a company incorporated in the host State.

No position is taken with regard to the question of whether any such assumptions, interpretations or definitions are applicable with regard to BITs in general or any particular treaty.

Reinier Kraakman et al., The Anatomy of Corporate Law (2d ed. 2009) [hereinafter Kraakman 2009]. The project has involved over a decade of work between authors from six countries: Reinier Kraakman (Harvard Law School), John Armour (University of Oxford), Paul Davies (University of Oxford), Luca Enriques (University of Bologna and Consob), Henry Hansmann (Yale Law School), Gerard Hertig (ETH Zurich), Klaus Hopt (former Director of the Max Planck Institute for Comparative and International Private Law, Hamburg), Hideki Kanda (University of Tokyo), and Edward Rock (University of Pennsylvania).

Eilís Ferran, Principles of Corporate Finance Law (2008).

As in the Preliminary Framework, for purposes of preliminary policy analysis, the following simplifying assumptions are made about SRL in ISDS under typical BITs: (i) both direct and indirect shareholders can bring ISDS claims; (ii) both controlling and minority shareholders can bring ISDS claims; (iii) shareholders can bring ISDS claims for both direct and reflective loss; (iv) shareholders have an autonomous right to claim in ISDS regardless of company recourse; and (v) company nationality (including the nationality of shareholders who are companies) is determined by the state of incorporation without any requirement of a "genuine link". This paper takes no position on whether these interpretations are correct with regard to BITs in general or any particular treaty. 
particular types of companies. ${ }^{12}$ Most investments at issue in ISDS appear to originate from business corporations.

The paper first outlines key functions of corporate law. It then examines the distinctive features of the business corporation and in particular its separate legal personality, the limited liability of its shareholders, the transferability of its shares and its delegated management through a board.

The paper then considers a number of additional policy issues relating to SRL that are suggested by the analysis of corporate law purposes and the business corporation. It notes that scholars have suggested that the legal rules creating the company's separate legal personality, including its ability to own assets in its own name, are especially important because, unlike most of corporate law, they cannot feasibly be replicated by contracts between the interested parties. In this context, it also preliminarily considers how market participants, and in particular creditors, may seek to respond over time to the availability of SRL in ISDS. $^{13}$

12 Closely-held corporations (e.g., the French SARL, the German GmbH, the Japanese or American close corporation and the UK private company) generally have relatively few shareholders and they may have important inter-relationships. Such companies typically have all of the core characteristics of the business corporation identified above. See John Armour, Henry Hansmann \& Reinier Kraakman, What is Corporate Law? [hereinafter Armour et al.], ch. 1 in Kraakman 2009, p. 17. However, while their shares are transferable in principle, they are frequently presumed (or required) not to trade freely in a public market. Closely-held corporations may be important actors in some types of foreign investment and may deserve special consideration.

Creditors are broadly defined to include contractual claimants on the company, including bondholders and other lenders, employees, suppliers and others. 


\section{B. FUNCTIONS OF CORPORATE LAW}

This section addresses important functions of corporate law including (i) defining recognised organisational forms possessing key attributes; (ii) reducing the costs of organising business through the corporate form by controlling agency costs (conflicts of interest); and (iii) permitting the corporation to serve as a distinct contracting party. ${ }^{14}$

\section{Defining recognised organisational forms possessing key attributes}

A principal function of corporate law is to provide business enterprises with easily-usable and recognisable legal forms that have key attributes. Company law or organisational law statutes in national law typically define a series of possible forms with different characteristics.

Comparative corporate law scholars have observed that all advanced systems of corporate law make available a form of entity, the company or business corporation, that has five key attributes: (i) legal personality; (ii) limited liability; (iii) transferable shares; (iv) centralised and delegated management under a board structure; and (v) investor ownership. ${ }^{15}$ The business corporation characterised by these five features is by far the most popular type of entity for large enterprises in advanced systems of corporate law.

National law typically also makes available other organisational forms that lack some of these attributes. ${ }^{16}$ However, they are much less frequently chosen by market participants for large-scale investment and business enterprise. The strong preference of market participants for the business corporation over other available forms may suggest that it is viewed as efficient. ${ }^{17}$

Selection of the business corporation form possessing the five core attributes allows participants and outsiders easily to know and expect application of well-known basic rules:

[A] given jurisdiction can provide for a menu of different standard form legal entities from which parties may choose in structuring an organization. ... Formation as a business corporation, for example, signals simply and clearly -- to all who deal with the firm, whether by purchasing shares or simply by contract -- that the firm is characterized by a variety of

14 Scholars recognise that corporate law in practice results from a political process and reflects the power of particular interests and influential constituencies. It also depends on its historical path of development in each jurisdiction. Armour et al., p. 29.

See Paul Davies, Luca Enriques, Gerard Hertig, Klaus Hopt, and Reinier Kraakman, Beyond the Anatomy, ch. 10 in Kraakman 2009, p. 305 ("the corporate form has the same fundamental legal features around the world: legal personality, limited shareholder liability, transferable shares, centralised (and delegated management), and investor ownership").

For example, corporate law in some advanced jurisdictions also provide for entities such as partnerships at will that do not require the same practically irrevocable commitment of capital to the enterprise as is provided by shareholders. Partners have the power to dissolve the partnership.

See Armour et al., pp. 1-2 ("These [five] characteristics respond ... to the economic exigencies of the large modern business enterprise. Thus corporate law everywhere must, of necessity, provide for them. To be sure there are other forms of business enterprise that lack one or more of these characteristics. But the remarkable fact - and the fact that we wish to stress - is that, in market economies, almost all large-scale business firms adopt a legal form that possesses all five of the basic characteristics of the business corporation"). 
familiar governance provisions, and that it will continue to have those characteristics unless and until it changes statutory form. ${ }^{18}$

Creditors and others who deal with the firm can address the risk of a change of the fundamental characteristics through a potential future change of statutory form by reserving a contractual veto on it. This can take the form of an acceleration clause in a loan agreement. ${ }^{19}$

\section{Reducing the costs of organising business through the corporate form by controlling agency costs (conflicts of interest)}

Another important function of corporate law identified by comparative scholars is to reduce the ongoing costs of organising business through the corporate form. It achieves this by facilitating cooperation between participants in the business enterprise and by reducing the scope for opportunism by participants.

Business corporations give rise to three principal types of conflicts among stakeholders: (i) between managers and shareholders; (ii) between shareholders; and (iii) between shareholders and the corporation's other constituencies, including creditors. Armour, Hansmann and Kraakman have suggested that much of corporate law can be equated to the search for optimal solutions to these three agency problems:

[An] important function of corporate law [is to] ... reduc[e] the ongoing costs of organizing business through the corporate form.... [M] uch of corporate law can usefully be understood as responding to three principal sources of opportunism: conflicts between managers and shareholders, conflicts among shareholders, and conflicts between shareholders and the corporation's other constituencies, including creditors and employees. All three of these generic conflicts may usefully be characterised as what economists call 'agency problems'.

Controlling agency problems can reduce a company's cost of capital by reducing the risk of opportunistic behaviour. In turn, this can increase the amount of investment by companies. ${ }^{21}$

\section{Permitting the corporation to serve efficiently as a distinct contracting party}

Another key function of corporate law is to allow the corporation to serve as an efficient mechanism for concluding contracts. Corporate law allows companies to contract with the many parties necessary to carry out complex joint projects bringing together inputs from many sources:

[A] firm serves, fundamentally, as the common counterparty in numerous contracts with suppliers, employees, and customers, coordinating the actions of these multiple persons through exercise of its contractual rights. The first and most important contribution of corporate law ... is to permit a firm to serve as ... a single contracting party that is distinct from the

\footnotetext{
$18 \quad$ See Armour et al., pp. 22-23.

19 Id., n.64.

Armour et al., p. 2.

21 See Eilís Ferran, Principles of Corporate Finance Law, p. 64 ("The company's cost of capital is a driving factor in decisions on whether to invest in new projects because these will only be worthwhile investments where they are expected to generate returns at least equal to the company's cost of capital.").
} 
various individuals who own or manage the firm. In so doing, it enhances the ability of these individuals to engage together in joint projects. ${ }^{22}$

Several of the key features of the business corporation contribute to allow it to contract efficiently as a distinct contracting party. ${ }^{23}$

Corporate law scholars frequently debate the issue of the overall purposes of corporate law. The debate often centres around whether the goal of corporate law should be to maximise shareholder welfare or whether it should serve broader goals. The comparative law project described here does not take a strong position in this debate. It notes that shareholder welfare is in any event best understood as taking into consideration the need for shareholders to obtain inputs from creditors, workers and customers who will only consent to deal with the company if they expect themselves to be better off as a result; they thus note that " $[\mathrm{t}]$ here would be little to recommend a body of law that, for example, permits corporate shareholders to enrich themselves through transactions that make creditors or employees worse off by $\$ 2$ for every $\$ 1$ that the shareholders gain". The project seeks to provides an analytical framework to allow for consideration of the ultimate goals of corporate law. See Armour et al, pp. 28-29. Consideration of corporate law insights with regard to SRL similarly does not appear to require resolution of the issue of the ultimate goals of corporate law. 


\section{CHARACTERISTIC FEATURES OF THE BUSINESS CORPORATION IN ADVANCED SYSTEMS OF CORPORATE LAW}

This section addresses the key features of the business corporation that have particular relevance to SRL. The second characteristic identified above, the limited liability of shareholders, is a familiar concept and one not put directly at issue by SRL; it can be addressed briefly. It protects the owners (shareholders) of the company by protecting their personal assets from the claims of the firm's creditors. Use of the corporate form means that, unless the parties contract otherwise, creditors of the company are limited to making claims against assets owned by the company. ${ }^{24}$

Three other characteristics - separate legal personality, delegated management and the transferability of shares - are addressed below because they may be directly affected by SRL and because some of them may be less familiar to some investment policy specialists.

\section{Separate legal personality}

As noted above, the first characteristic of the business corporation is its separate legal personality. Separate legal personality refers to a number of key attributes of the corporation that allow it to serve as an efficient contracting party. These include (i) "entity shielding" - protection of the company's assets from its shareholders and the personal creditors of those shareholders; (ii) the ability of the company to sue and be sued in its own name; and (iii) specific rules regarding who has authority to act in the name of the company.

\section{a. $\quad$ Entity shielding}

The most important aspect of separate legal personality has been termed "entity shielding" because it protects the entity (the company). ${ }^{25}$ Entity shielding protects the firm's assets from shareholders and their personal creditors. The notion of entity shielding has been derived and developed from the civil law notion of a separate patrimony:

The core element of the firm [as a separate contracting entity distinct from the owners or managers of the firm] is what the civil law refers to as "separate patrimony". This involves the demarcation of a pool of assets that are distinct from other assets owned, singly or jointly, by the firm's owners (the shareholders), and of which the firm in itself, acting through its designated managers, is viewed in law as being the owner. The firm's rights of ownership over its designated assets include the right to use the assets, to sell them and - of particular importance - to make them available for attachment by its creditors. Conversely, because these assets are conceived as belonging to the firm, rather than the firm's owners, they fact that in business corporations, ownership -- understood as the right to control the firm and the right to receive the firm's net earnings -- is tied to investment of capital in the firm. See Armour et al., p. 14. Both rights are typically proportional to the amount of capital invested in the firm. The business corporation, as a special statutory form for corporations owned by investors of capital and adapted to their needs, helps to "signal[] clearly to all interested parties the particular character of the firm with which they are dealing". Id., p. 15) This characteristic excludes from the scope of the comparative analysis of business corporations other types of firms that are not investor-owned, such as cooperatives or non-profit entities.

Armour et al., p. 6. 
are unavailable for attachment by the personal creditors of these persons. The core function of this separate patrimony has been termed 'entity shielding', to emphasize that it involves shielding the assets of the entity the corporation - from the creditors of the entity's owners. ${ }^{26}$

Entity shielding involves two relatively distinct rules of law. The first is a rule establishing priority for access to company assets. Entity creditors have priority claims over entity assets. The claims of entity creditors to company assets come before the claims of shareholders (or their personal creditors). The rule makes company assets automatically available to back up the company's contractual commitments. Creditors' priority helps make the company's contractual commitments credible. ${ }^{27}$

A second legal rule providing entity shielding gives liquidation protection to the entity. It avoids partial or complete liquidation of the company by preventing shareholders (or their personal creditors) from withdrawing their share of firm assets at will. ${ }^{28}$ Liquidation protection helps preserve the going concern value of the company which is generally of value to both creditors and shareholders. ${ }^{29}$ It also avoids the need to evaluate the relative claims of all corporate constituencies to entity assets.

On its own, the priority rule establishes what has been termed "weak" entity shielding. Together, the priority rule and liquidation protection establish "strong" entity shielding. ${ }^{30}$

Together, entity shielding and limited liability (owner shielding ${ }^{31}$ ) set up two separate pools of assets: business assets are pledged as security to business creditors, while the personal assets of shareholders are reserved for those shareholders' personal creditors. ${ }^{32}$

Armour et al., p. 6 (emphasis in original).

See Armour et al., p. 7 ("The consequence of this priority rule is that a firm's assets are, as a default rule of law, automatically made available for the enforcement of contractual liabilities entered into in the name of the firm. By thus bonding the firm's contractual commitments, the rule makes these commitments credible.") (footnote omitted).

Scholars have noted that the risk of liquidation through loss of entity assets can originate both from shareholders and their personal creditors (in the event of shareholder insolvency). See Henry Hansmann, Reinier Kraakman \& Richard Squire, Law and the Rise of the Firm, 119 Harv. L. Rev. 1333, 1338 (Mar. 2006) (highlighting risk from shareholders' personal creditors, who are not bound by contracts between shareholders and company creditors); Margaret M. Blair, Locking in Capital: What Corporate Law Achieved for Business Organizers in the Nineteenth Century, 51 UCLA L. Rev. 387, 392 (Dec. 2003) (highlighting the risk from shareholders themselves: "Perhaps as important as protecting the assets of the enterprise from participants' creditors, however, was the role that incorporation played in establishing a pool of assets that was not subject to being liquidated or dissolved by any of the individual participants who might want to recover their investment.") (emphasis in original).

Preserving going concern value is important because companies are often worth more both to their creditors and their shareholders as a going concern rather than as piece-meal assets upon liquidation. Creditors often refrain from fully enforcing their rights in order to preserve the going concern value of an insolvent firm. See John Armour, Gerard Hertig and Hideki Kanda, Transactions with Creditors, ch. 5 in Kraakman 2009, p. 122 ("Of course, creditors often would rather not have a distressed firm actually go into formal bankruptcy proceedings. This is because a firm's bankruptcy calls its future into question, with the consequence that its suppliers and customers downgrade their expectations about its commitment to performance - which, in turn, reduces the value that can be obtained by selling the firm's assets. Hence it is common for firms to seek to effect a 'workout' with their creditors (a restructuring in the shadow of bankruptcy proceedings) rather than go into formal proceedings.”)

Armour et al., p. 7. 
In all advanced corporate law systems, the most popular corporate entity for large-scale investment, the business corporation, is characterised by strong entity shielding and limited liability. Company shareholders benefit from limited liability: their exposure to losses is normally limited to the amount of their investment in their shares. Company creditors have a priority claim over corporate assets: in the event of entity insolvency, company creditors must be fully paid out before shareholders can recover any of their investment. Shareholders' investments in the company are also generally permanent and "exit" for shareholders is only rarely available and under carefully controlled circumstances (and in some systems not at all). Shareholder capital is in effect "locked in" subject to limited exceptions. ${ }^{33}$ Weak entity shielding is found in partnerships which are rarely used for major long-term investment.

\section{b.}

The capacity of the company to sue and be sued in its own name

A second key aspect of the company's separate legal personality is its ability to sue and be sued in its own name. While entity shielding helps ensure that the company's contractual commitments are backed up by assets, the ability to sue and be sued relates to procedural issues.

Rules in this area specify the procedures by which the firm can sue, including on its contracts, and those by which it can be sued. The law in advanced jurisdictions makes such suits easy to bring against a business corporation as a procedural matter. The company as a whole can be sued by, for example, providing it with a single notice to a specified recipient. There is no need to identify or serve notice on shareholders. Similarly, the company has the power to bring suit in its own name without reference to its owners. In some cases, these simplifying modern rules eliminated some earlier rules for suits that required that individual owners be named and notified. ${ }^{34}$

\section{c. Defining who can bind the company: the question of authority over the separate legal entity}

In order to enter into contracts with a company, third parties need to know who has authority to contract in the name of the company and to buy and sell company assets. For internal purposes, participants in a firm can contract on specific rules for the delegation of authority. For external purposes, however, legal rules are needed to address cases where agents of the company induce third parties to rely on their apparent authority. ${ }^{35}$ In the context of the business corporation, the board of directors, as opposed to shareholders, generally has this authority, as explained below.

31 Limited liability has been referred to as "owner shielding" because it shields the owners of the company (shareholders) from liability for the company's debts.

This separation of assets into two pools has been called asset partitioning. See Armour et al., p. 6 n.12; Henry Hansmann \& Reinier Kraakman, The Essential Role of Organizational Law, 110 Yale Law Journal 387 (2000); see also Margaret M. Blair, Locking in Capital: What Corporate Law Achieved for Business Organizers in the Nineteenth Century, 51 UCLA L. Rev. 387, 391 (Dec. 2003) ("Partitioning has two aspects: Individual participants in the business are not held personally responsible for the debts or liabilities of the business (this aspect is commonly referred to as limited liability in the context of business corporations), and participants and third parties are assured that the pool of assets used in the business will be available to meet the needs of the business first (such as, to pay the claims of the business's creditors) before these assets can be distributed to shareholders") (footnotes omitted; emphasis in original).

See Preliminary Framework, p. 17 (noting emphasis in German case law and scholarship on the principle that the company's assets are bound for the purpose of the business (Zweckwidmung des Gesellschaftsvermögens)); see also Margaret M. Blair, Locking in Capital: What Corporate Law Achieved for Business Organizers in the Nineteenth Century, 51 UCLA L. Rev. 387 (Dec. 2003).

Armour et al., p. 8.

Armour et al., p. 8. 


\section{Delegated management by a board}

Like separate legal personality, delegated management is a core characteristic of the business corporation. Absent special agreement to the contrary, shareholders who form a company agree that almost all business decisions will be taken by the board of directors (or by management subject to monitoring by the board) rather than shareholders directly. Corporate law identifies a small number of fundamental changes for which shareholder approval is required, but otherwise leaves most decisions to the board. ${ }^{36}$

The board is formally distinct from the shareholders even though it is typically selected by them. This can have both efficiency and fairness benefits. It streamlines corporate decision-making because most decisions can be taken without the need to inform or obtain the consent of shareholders. Delegated management by a board charged with considering the best interests of the company can also help protect vulnerable corporate constituencies, particularly if the board includes independent directors:

[T]hough largely or entirely chosen by the firm's shareholders, the board is formally distinct from them. This separation economizes on the costs of decision-making by avoiding the need to inform the firm's ultimate owners and obtain their consent for all but the most fundamental decisions regarding the firm. It also permits the board to serve as a mechanism for protecting the interests of minority shareholders and other corporate constituencies. ${ }^{37}$

Decisions to commence or settle litigation, particularly against a regulatory body or government entity, can be some of the most sensitive corporate decisions taken by the board. While shareholders and particular major shareholders may make their views known to the board, the board retains the ultimate responsibility to make the decisions for business corporations. ${ }^{38}$

\section{The transferability of shares}

The transferability of shares is another core characteristic of the business corporation in advanced systems of corporate law. Transferability allows the firm to continue to conduct business notwithstanding changes in its ownership and enhances the liquidity of shareholders' interests:

Transferability permits the firm to conduct business uninterruptedly as the identity of its owners changes, thus avoiding the complications of member withdrawal that are common among, for example, partnerships, cooperatives, and mutuals. This in turn enhances the liquidity of shareholders' interests and makes it easier for shareholders to construct and maintain diversified investment portfolios. ${ }^{39}$

36

The discussion focuses on companies with a single board. Some corporate law systems, such as in Germany, provide for two separate boards with different responsibilities. These differences do not affect the basic delegation of management responsibility by shareholders addressed here.

Armour et al., p. 14. Specific reforms in some jurisdictions may give shareholders rights to vote on certain specific issues, such as executive compensation.

The board may further delegate decisions relating to litigation to company officers, but the officers operate subject to monitoring by the board.

Armour et al., p. 11. 
While, as noted above, shareholders cannot recover their investment from the company, they can seek to recoup their investment by selling their shares to a third party. ${ }^{40}$ Where shareholders do not have access to company assets and benefit from limited liability, the transfer of shares to a third party generally does not significantly affect the creditworthiness of the company. ${ }^{41}$

The existence of this transferability - share transfers that do not cause a substantial impact on the firm's creditworthiness - requires both strong form entity shielding (liquidation protection) and limited liability:
Absent either [strong form entity shielding or limited liability], the creditworthiness of the firm as a whole could change, perhaps fundamentally, as the identity of its shareholders changed. Consequently, the value of shares would be difficult for potential purchasers to judge. ${ }^{42}$

The fungibility of shares of the same class, which generally have equal rights, is also important to their transferability. For example, it can allow shares to be sold electronically without a document of transfer. ${ }^{43}$

Transferability here is distinguished from freely tradable shares. Trading in shares may be restricted to limited groups of individuals or require the approval of shareholders or the company. In the UK, shares in limited companies are freely transferable unless the articles of association of a particular company restrict dealings. See Eilís Ferran, Principles of Corporate Finance Law, p. 24.

In specific situations, such as where it is expected that an existing important shareholder would support the company, a transfer of shares to a third party may affect the creditworthiness of the company.

Armour et al., p. 12.

See Ferran, pp. 163, 24. 


\section{CONSIDERATION OF CORPORATE LAW MAY SUGGEST ADDITIONAL POLICY ISSUES RELATING TO SHAREHOLDER CLAIMS FOR REFLECTIVE LOSS IN ISDS}

As noted above, the discussion at the Roundtable in March 2013 focused on the consistency issues raised by SRL. Consideration of broader context of the goals and purposes of advanced systems of corporate law may help government identify additional policy considerations relevant to SRL. This section analyses the potential impact of SRL on the three characteristic features of the business corporation addressed above. ${ }^{44}$

\section{Separate legal personality}

As outlined above, corporate law provides important benefits in the form of predictability and legal certainty to investors. The selection by investors of a particular corporate form signals commitment to specific rules with regard to, among other things, the relationships between shareholders, creditors and the company. In this respect, corporate law shares with investment law a similar focus on enhancing legal certainty and predictability.

Entity shielding may be among the most important of these rules for business corporations. Investors in companies assume that shareholders do not have access to corporate assets because national law precludes such access. The introduction of different rules may upset the settled expectations of markets about the corporate form as a structure for investment.

\section{a. $\quad$ Policies relating to the impact of SRL on entity shielding \\ i. $\quad$ Benefits and costs of entity shielding}

Law and economics scholars have suggested that the permanency of shareholder investment that is assured by entity shielding allows the firm to draw in other valuable resources including from other investors, and to rely on the existence of shareholder capital for long-term projects. Recent research has suggested that law providing for entity shielding and the locking in of share capital was important for the historical development of large-scale enterprises and economic growth in various jurisdictions:

[O]nce the funds paid to purchase those shares had been committed, limits were imposed - sometimes severe ones - on the ability of investors to withdraw funds from the business. The commitment of capital by shareholders ... helped protect the at-risk investments made by other corporate participants. ... [T] he capital contributed or pledged in the form of equity shares helped secure a pool of "bonding assets," which made it easier to draw in other risky contributions to the enterprise. ${ }^{45}$

Similarly, in reviewing the historical development of entity shielding in continental Europe, Naomi R. Lamoreaux and Jean-Laurent Rosenthal suggest that "[f]irms needed entity shielding to take on many of

\footnotetext{
$44 \quad$ As noted in the Preliminary Framework, p. 31, shareholder claims regimes are typically the object of intensive study in the context of any proposed reforms, a process that does not appear to have occurred with regard to the rules on SRL in ISDS under typical BITs. 
the economic activities that were important in advanced industrial economies". ${ }^{46}$ Scholars have suggested that the benefits of the corporate form may be relevant to issues of economic development:

The corporate form does not now seem so unique or remarkable, so that its benefits might seem trivial. But it is worth exploring what it was that made the corporate form so attractive to business organizers as the U.S. economy moved from an agrarian, small-scale production economy to a large and modern industrial economy. ... [U]understanding this process may help shed light on the problems plaguing the economic transitions underway around the world ... I suggest that entity status, together with legal separation of governance, helped to protect and encourage coordinated, specialized investments by all of the constituents of the enterprise. ${ }^{47}$

Entity shielding is not without costs. For example, entity shielding can allow those in control of the firm to behave opportunistically toward minority shareholders because the latter are generally unable to withdraw their investment. However, as noted, in all advanced systems of corporate law, entity shielding is made available in the business corporation and is widely chosen by market participants. Corporate and other law seeks to manage the potential costs of entity shielding through many devices such as the imposition of fiduciary duties on directors or constraints on transactions by the company with related parties.

Scholars have summarised a number of specific benefits of entity shielding:

- Entity shielding allows the firm to make contractual and other commitments that are credible.

- Entity shielding facilitates the company's access to credit.

- Entity shielding can reduce agency costs and thus the overall cost of capital to the firm and its owners.

- Entity shielding permits firms to isolate different lines of business for the purposes of obtaining credit. Creditors for a particular venture are frequently capable of monitoring the assets used in that venture, but have little ability to monitor the parent company's other ventures. More generally, it allows risks to be shared with the firm's creditors in a foreseeable way.

- Together with limited liability, it facilitates the administration of both business and individual insolvency. Forms: A Comparative Perspective, 119 Harv. Law Rev. Forum 238 (Mar. 2006); Robert C. Clark, Corporate Law (1986) $\S 1.2 .3$ (noting that because any partner can dissolve a partnership by express will at any time and withdraw its investment, “[t]he partnership's life is thus a precarious one, and this fact will give pause to those wanting to launch a large enterprise with large start-up costs"; contrasting the corporate entity in which individual shareholders cannot withdraw their investment, leading to a more stable existence that is "more likely to preserve the going concern value of large projects").]

Margaret M. Blair, Locking in Capital: What Corporate Law Achieved for Business Organizers in the Nineteenth Century, 51 UCLA L. Rev. 387, 397 (Dec. 2003). 
(a) SRL may impose additional risks and costs on creditors

As noted above, entity shielding protects creditors by (i) ensuring that they have a priority claims on corporate assets that comes before any shareholder claims; and (ii) preventing partial or complete liquidation of the firm, thus protecting its going-concern value.

In the case of third-party injury to the company (the SRL context), the company has generally already incurred a loss. The SRL intervenes at a moment when the company is already weakened. What is at issue is the company's capacity to reconstitute its assets and expectations about that capacity.

For creditors (and non-claiming shareholders), the availability of SRL in ISDS may mean that regulatory risk may be compounded by (i) liquidation risk because SRL may prevent the company from reconstituting its assets following the government injury; and (ii) priority risk because it is unclear whether ISDS arbitrators will be interested in creditor claims or able to prioritise them adequately (see below the section on reliance on ISDS arbitrators taking account of creditor interests).

The uncertainties caused by SRL with regard to company assets may also affect other advantages of entity shielding outlined above, including the ability of the firm to serve as a single contracting party and make credible commitments, and its ability to use its assets to obtain credit. Its cost of credit and thus its overall cost of capital may be affected.

\section{Box 1. Risks to creditors and tax authorities from assets being moved around shareholder ownership chains}

The Preliminary Framework (p. 33) noted that SRL in ISDS can facilitate treaty shopping by allowing a shareholder to claim for company loss at its preferred level of the shareholder's chain of ownership. Shareholder ability to move claims around within an ownership structure using SRL may also be used to provide benefits to shareholders in a fashion detrimental to creditors (and tax authorities). Advanced national corporate law does not permit SRL, but similar issues can arise from actions taken by controlling shareholders in the context of a corporate group:

A group structure allows controllers to set the terms of intra-group transactions, and thus to assign (and reassign) value within the group. Sometimes an intragroup transaction is designed solely in order to extract value from the creditors of a financially distressed group member or to favour the creditors of one subsidiary to the detriment of the creditors of other group members. Yet creditors may also suffer harm as a by-product of intra-group asset transfers undertaken for other reasons - for example, to secure a tax advantage.

The availability of SRL in ISDS may give rise to broader scope for this type of opportunism than under national corporate law. First, any shareholder, rather than only controlling shareholders, can choose the (covered) level at which to bring its SRL for company loss. Second, the intra-group transactions described above generally involve at least some payment for the valuable asset, albeit one below its real value. In the case of a shareholder decision to locate its $S R L$, the non-claiming entities do not receive any compensation. The potential problems for creditors may be compounded by the lack of transparency in ISDS.

* John Armour, Gerard Hertig and Hideki Kanda, Transactions with Creditors, ch. 5 in Kraakman 2009, p. 127; compare id. p. 116 (noting risk of shareholder opportunism vis-a-vis creditors by falsely claiming that the firm holds title to assets that actually belong to other entities or to the shareholders personally). 
(b) Creditors may consider that SRL will frequently be brought in cases of injury to the company by a government

Creditors may also consider that, if they are available, SRL are likely to be attractive in many cases of company injury for several reasons. ${ }^{48}$ First, as outlined in the ISDS Scoping Paper, other than for expropriation, advanced systems of administrative law generally do not provide damages remedies to investors. ${ }^{49}$ In contrast, access to SRL in ISDS gives shareholders access to damages for non-expropriation claims. This may make shareholder claims more attractive than company claims in many contexts.

Even where the company has a claim in damages, as under a contract, shareholder claims may be more attractive than a company claims. ${ }^{50}$ Shareholders making SRL in ISDS may in some cases have "better rights" than the company, as suggested by a recent law firm description of shareholder claims in ISDS. $^{51}$

(c) SRL may also affect relationships between shareholders

The availability of SRL for some shareholders but not others may give the former increased leverage within the company and affect negotiations on various issues. Most directly, it may be likely to affect decisions about how to respond to alleged government misconduct affecting the company.

\section{b. $\quad$ Impact on the capacity of the company to sue and be sued in its own name}

As a rule applying to litigation, SRL directly affects the procedures for suits involving companies. The simple procedural rules that have been developed for suits involving companies are not adapted to SRL. For example, claims by the company are not fully resolved by a company claim; shareholders have rights to claim as well. To avoid the risk of double jeopardy, shareholders need to be joined to the suit so that they are bound by the outcome. If multiple suits are to be avoided, appropriate procedural rules need to be in place to allow for the identification and joinder of shareholders. These issues are similar to the consistency issues addressed in the Preliminary Framework. ${ }^{52}$

48 In this section, references to shareholders refer generally to shareholders covered by an investment treaty; where clarification is needed, covered and non-covered shareholders are distinguished.

See David Gaukrodger \& Kathryn Gordon, Investor-State Dispute Settlement: A Scoping Paper for the Investment Policy Community (Dec. 2012) ("ISDS Scoping Paper"), pp. 25-27 \& Annex 4.

In addition to expropriation cases, investors typically have damages remedies against governments in cases of breach of contract. (The ISDS Scoping Paper focused on non-contractual claims. See ISDS Scoping Paper, p. 80 \& n.196.).

See Matthew Weiniger, Legal Standing of Shareholders in International Law, pp. 12,14 (May 2011) (suggesting that in CMS v. Argentina the tribunal in effect found that the minority shareholder claimant had "different (and better!) rights than [the company which signed the contract]" and that "[a]ll investment treaty tribunals and annulment committees support the CMS conclusion").

As outlined in the Preliminary Framework, these can include multiple high-cost claims for the same injury; difficulties in achieving a settlement due to the need for shareholder consent; potentially inconsistent results; risks of double recovery; and risks of a single shareholder having "two bites at the apple". 


\section{c. Corporate law rules creating the company's separate legal personality, which are generally considered to be value-enhancing, may not be replicable by contract}

Hansmann, Kraakman and Squire have suggested that the mandatory corporate law rules creating the company's separate legal personality and in particular its entity shielding in advanced jurisdictions are of fundamental importance because their enhancement of company value cannot be replicated by contract:

All entity forms used by modern commercial firms exhibit entity shielding. ... [E]ntity shielding, unlike [limited liability], can be achieved only through the special property rules of entity law. For this reason, we believe that entity shielding is the sine qua non of the legal entity .... ${ }^{53}$

This perceived need for legal rules distinguishes separate legal personality from the other core characteristics of the business corporation which can be replicated by contract. ${ }^{54}$

The perceived need for legal rules is based on the practically insurmountable hurdles to achieving the same result by contract. If the law allows shareholders to have access to corporate assets, establishing entity shielding by contract would require each shareholder to agree by contract to subordinate its personal claims on those assets to those of company creditors. Each shareholder would also need to obtain a similar subordination agreement from all its personal creditors over time.

Even for a single direct shareholder (entrepreneur), this has been described as practically impossible to achieve by contract in light of the various incentives and obstacles:

[T]o assure his business creditors a prior claim on his business assets, the entrepreneur would need to promise them credibly that he would obtain from all of his personal creditors, both past and future, agreements subordinating their claims on the entrepreneur's business assets to those of the entrepreneur's business creditors. Absent organizational law, an entrepreneur would generally be both unwilling and unable to make a credible promise of this sort. He would be unwilling because the costs of obtaining the necessary subordination agreements would be prohibitive in virtually any practical situation. He would be unable because his compliance could not be monitored or bonded. ${ }^{55}$

The situation is further complicated if there are multiple direct shareholders and share transfers. ${ }^{56}$

53 Henry Hansmann, Reinier Kraakman \& Richard Squire, Law and the Rise of the Firm, 119 Harv. L. Rev. 1333, 1338 (Mar. 2006) (footnotes omitted); see also Armour et al, p. 8 ("Entity shielding doctrine [imposed by law] is needed to create common expectations, among a firm and its various present and potential creditors, concerning the effect that a contract between a firm and one of its creditors will have on the security available to the firm's other creditors.").

See Armour et al., p. 37 ("of the five defining characteristics of the corporate form, only one -- legal personality - clearly requires special rules of law").

Henry Hansmann \& Reinier Kraakman, The Essential Role of Organizational Law, 110 Yale Law Journal 387, 407 (2000).

See Hansmann et al, Law and the Rise of the Firm, 119 Harv. L. Rev. at pp. 1340-41:

It would be practically impossible in most types of firm to create effective entity shielding without special rules of law. Entity shielding in general limits the rights of personal creditors by subordinating their claims on firm assets, and strong entity shielding additionally impairs the ability of personal creditors to liquidate firm assets. Although a firm's owners in theory could achieve either of these 
If the law goes further and allows indirect shareholders access to corporate assets, the obstacles to a contractual solution to re-establish entity shielding are further multiplied. Even if it were possible to achieve contractual agreements by all direct shareholders and their creditors to subordinate their claims to the company claim, the agreement could be circumvented by claims by a higher-tier indirect shareholders or their creditors.

Armour, Hansmann and Kraakman similarly suggest that, in addition to entity shielding, other key aspects of separate legal personality also require legal rules. This includes the capacity of the company to sue and be sued in its own name and the determination of the persons who have authority to bind the company vis-a-vis third parties. ${ }^{57}$

\section{Impact of shareholder claims for reflective loss on centralised and delegated management by a board}

As noted above, centralised management of the company by a board is generally considered to have a number of benefits. These include promoting efficiency by streamlining corporate decision-making -eliminating the need to inform or obtain the consent of shareholders -- and protecting vulnerable corporate constituencies.

SRL affects the principles governing the delegation of management to the board of directors. Instead of the board having control of the litigation decision, covered shareholders can individually decide whether to claim for their part of injury to the company, decisions which may significantly alter the business environment for the company as a whole. Individual covered shareholders such as hedge funds may have interests that diverge significantly from those of the board with regard to maintaining the value of a brand or the importance of maintaining a constructive long-term investment relationship in the host jurisdiction. ${ }^{58}$

As noted in the Preliminary Framework, derivative actions generally do not raise the same issues as SRL because recovery of damages goes to the company and multiple suits are generally precluded. One of

results by negotiating for the requisite waivers in all contracts with their personal creditors, the negotiation of such waivers - beyond involving high transaction costs - would be fraught with moral hazard. Each waiver would improve the position of firm creditors and thus benefit all firm owners by decreasing the firm's borrowing costs. But each waiver would also increase personal borrowing costs, and that cost would be borne entirely by the owner who negotiated the waiver. Each owner would thus face an incentive to act opportunistically by omitting the waivers from personal dealings. Moreover, other owners and firm creditors would find such omissions costly to police, given the significant freedom individuals enjoy in their personal dealings. A larger number of owners exacerbates the problem by making monitoring more difficult and by heightening the conflict between personal and collective interests. And the policing problem is further compounded if ownership shares are freely transferable. These problems can be solved only by impairing the rights of personal creditors without their contractual consent (and often even without notice). Doing that requires a special rule of property law for assets committed to the firm. Entity law provides that rule. (footnotes omitted).

See Armour et al., p. 8.

As noted in the ISDS Scoping Paper, one of the reasons explaining the very few investor claims for damages under advanced systems of national administrative law may be that companies with long-term relationships hesitate to claim against a regulatory body with which they have an on-going relationship. See ISDS Scoping Paper, p. 87 (exploring possible explanations for the absence of damages claims by investors under domestic systems and suggesting that, in addition to legal obstacles to recovery of damages, investors may be hesitant to sue because of broader government and regulatory relations concerns in jurisdictions where they are long-term players). The prohibition on SRL likely also plays a role in this regard: at least some shareholders, if domestic law permitted them to claim, might have a different perspective on the costs and benefits of a claim against a regulatory entity than the company board. 
the concerns raised by shareholder derivative actions in advanced domestic law, however, is their potential impact on corporate governance and interference with management of the company by the board. For this reason, domestic derivative action mechanisms typically give priority to the company decision about whether to sue unless the shareholder can demonstrate that the board is disqualified by a conflict of interest.

\section{Impact on transferable shares}

The availability of SRL for some shareholders but not others introduces differences between shareholders. ${ }^{59}$ These differences may raise a number of policy issues for governments relating to the transferability of shares and the transfer of rights to bring SRL.

\section{a. $\quad$ Share transfers may affect company creditworthiness}

As noted in the Preliminary Framework, where the company is the sole entity that can bring the claim for its injury, shareholders can dispose of and acquire indirect interests in the outcome of the company claim. The selling shareholder gives up its indirect interest in the claim and the acquiring shareholder obtains the same interest. The interest accompanies the shares. The company litigation, as such, normally does not affect the liquidity of the market for its shares.

Where SRL are available in ISDS, covered shareholders (but not other shareholders) can pierce strong form entity shielding if they consider that government misconduct has injured the firm. Consequently, a transfer of shares between shareholders may have consequences for the creditworthiness of the firm. This will particularly be the case with regard to transactions involving "likely claimant" (Category I) shareholders. ${ }^{60}$

\section{b. Transfers of shares and transfers or retention of rights to bring SRL}

Given the recent development of SRL, the law on the transfer by shareholders of rights to bring SRL in ISDS appears to be less than fully developed, although research to date has been limited. One issue, for example, could arise in the context of companies with "pre-claim" ISDS regulatory disputes (ones that have not yet given rise to a shareholder claim). With SRL, a covered shareholder of such a company has rights to claim in ISDS with regard to possible past government misconduct towards the company. Questions may arise with regard to the ability of a selling covered shareholder to transfer or retain its ISDS rights in the context of a pre-claim sale of the shares to a new shareholder.

For example, a covered shareholder may have held shares from 2008-2013. The government may have taken certain questionable actions towards the company during that time. However, no shareholder

59 Compare Stanimir Alexandrov, The "Baby Boom" of Treaty-Based Arbitrations and the Jurisdiction of ICSID Tribunals: Shareholders as "Investors" and Jurisdiction Ratione Temporis, The Law and Practice of International Courts and Tribunals, Vol. 4 (2005) 19, 45 (finding that ISDS tribunals considering shareholder claims "all considered it to be beyond doubt that a shareholder's interest in a company includes an interest in the assets of that company, including its licenses, contractual rights, rights under law, claims to money or economic performance, etc.") with Ferran, Principles of Corporate Finance Law, p. 147 (Under UK law, "[t]he shareholder's financial interest is in the company itself and it does not amount to a direct interest in the company's assets.").

For the division of shareholders into categories, see Preliminary Framework, pp. 47-48 (noting that where SRL are available, company shareholders likely fall into three broad categories: Category I (likely claimants) - covered shareholders with substantial investments); Category II (potential but unlikely claimants) - covered shareholders but with smaller investments or a diversified investment strategy; and Category III (excluded claimants) - those not individually covered by a treaty. 
claim has been filed. In a transfer of the shares in 2013, questions may arise about whether (i) the selling shareholder can retain its ISDS rights to claim with regard to those events while selling the shares; or (ii) whether it can transfer to the acquirer its rights to claim reflective loss with regard to the 2008-2013 events. Because SRL are generally barred under national law, there are unlikely to be cases or rules establishing a regime for transfer of such rights.

It would appear that, if SRL are available, policy issues may arise regardless of the regime for transfers or retention of SRL. For example, in the pre-claim scenario outlined above, at least three different regimes are possible. ${ }^{61}$ First, the law may prohibit the selling shareholder from (i) separating out and retaining its right to claim for SRL while selling the shares; or (ii) transferring its (pre-claim) rights to reflective loss to the acquiring shareholder. Under this hypothesis, the selling shareholder may hesitate to sell its shares. The shares (with the possible SRL) may be more valuable to the seller than to the buyer (without those rights). This could affect the liquidity of the market for shares of the injured company. Alternatively, the selling shareholder could agree to file an early claim to benefit from possibly more lenient rules about post-claim transfers of rights to SRL; this could lead to unduly early filings of possibly meritless shareholder claims primarily to allow share transfers without loss of the SRL rights.

Second, the law may preclude the transfer to the purchaser of the right to bring SRL, but allow the selling shareholder to retain it. Under this hypothesis, selling shareholders will likely seek to retain their SRL rights (while selling the rest of the rights relating to the shares). Acquirers may be indifferent to the seller's preferences in this respect: if the law prohibits acquirers from acquiring the SRL rights relating to past conduct, acquirers may not object if the seller seeks to retain them. The separation of SRL rights relating to past government conduct relating to the company from current share ownership may lead to complications for respondent governments and company creditors. Issues could include how to identify and include such former shareholders with SRL rights in settlement negotiations.

Third, the law could permit the transfer of SRL rights with regard to past conduct to the acquiring shareholder. Under this hypothesis, the basic principle that pre-investment conduct is not actionable could be largely eliminated. ${ }^{62}$ An investor could acquire shares with awareness of the alleged misconduct vis-avis the company and then file its SRL damages based on that misconduct after acquiring the shares. The resulting market for rights to bring SRL could disrupt company relations with regulatory authorities; a new covered shareholder could at any point institute a claim about past events. ${ }^{63}$

The lack of national law precedents may mean that, in the absence of guidance, expensive litigation is required before the rules on transfer are stabilised through case law. ${ }^{64}$

61 These hypothetical approaches are identified here solely for purposes of policy analysis. No view is expressed about whether any of them is a correct interpretation of any particular investment treaty or treaties in general.

See Campbell McLachlan et al., International Investment Arbitration: Substantive Principles (2007) $\S$ 7.105 (noting the general principle that "the investor must take the conditions of the host State as he finds them. He cannot make a subsequent complaint if his investment fails merely because of laws, policies or practices which were in place at the time of the investment, and which were, or ought to have been, well known to him before making the investment.") (citing The Oscar Chinn Case (1934) PCIJ Rep Series A/B No. 63).

A particular treaty may also impose nationality restrictions that must be satisfied for a valid transfer of the rights. To simplify the analysis, it is assumed here that the transfers satisfy those requirements.

The discussion here is focused on hypothetical regimes for transfers of SRL rights in the context of voluntary transfer of shares. Involuntary share transfers in the context of shareholder insolvency may raise additional uncertainties in ISDS with regard to the transfer of SRL rights to a trustee in bankruptcy. 


\section{E. POSSIBLE RESPONSES BY INVESTORS TO THE AVAILABILITY OF SHAREHOLDER CLAIMS FOR REFLECTIVE LOSS}

The availability of SRL for certain shareholders benefits those shareholders, but raises a number of concerns for other corporate constituencies, including creditors and the other shareholders. It is important to consider the likely responses of these constituencies to the new rules in ISDS. This section outlines a few initial considerations. The preliminary discussion here focuses on covered foreign shareholders who are likely claimants in the event of company injury (Category I shareholders) and creditors.

\section{Increased investment by Category I (likely claimant) shareholders}

As noted in the Preliminary Framework, Category I shareholders are likely the principal beneficiaries of the rules on SRL in ISDS. The additional rights given to such shareholders in ISDS should encourage investment by them. The differences in the rights of foreign as opposed to domestic shareholders may lead to a significant increase in foreign share ownership by Category I shareholders. In some cases, depending on applicable law, this may reflect transaction structuring to obtain foreign status rather than real flows.

\section{Potential responses by creditors to the availability of shareholder claims for reflective loss}

In advanced systems of corporate law, contracts with a corporation are drafted against the background of well-established law providing for its separate legal personality and generally barring SRL. For example, the contracting parties to a loan generally do not need to address the risks of shareholder claims in the loan contract.

Because creditors do not need to worry about SRL in domestic law, identifying potential creditor responses to the expected availability of such claims by shareholders of the debtor company in ISDS is somewhat speculative. As discussed above, it would appear difficult to recreate the company's separate legal personality by contract. In the absence of legal rules, creditors may take other actions to protect their investments.

Most of the potential responses outlined here may not be meaningfully available to smaller or local creditors even if they are aware of the additional risks created by ISDS. Higher risks for creditors may fall in particular on them.

\section{a. Lending at a different level in the corporate chain}

The creditors of a bottom- or mid-tier company may be exposed if a higher tier shareholder makes an ISDS claim for reflective loss. As seen in the Lauder/CME cases, recovery for the top-tier shareholder would normally not benefit the lower-tier CME bondholders. ${ }^{65}$ As noted above, a shareholder may be able to choose its preferred level to bring its claim. ${ }^{66}$

One potential creditor response to this risk could be to seek to lend to a higher tier shareholder or even the ultimate controlling shareholder rather than to a lower-tier entity. A loan to the ultimate controlling

65 See Preliminary Framework, pp. 49-50 \& Figure 5 (on p. 42).

As elsewhere with regard to reflective loss, the assumption that the injured company has effective recourse is generally important. See Preliminary Framework, p. 19. However, issues may be raised for creditors regardless of whether the operating company in the host state can recover in ISDS. The availability of ISDS claims along the corporate chain can allow a shareholder to choose to bring a treaty claim at a higher level to circumvent lower-tier creditors. 
shareholder directly would ensure that the creditor is not lending to an entity that is too low in the chain to benefit at all from the shareholder recovery. Shareholder recovery at whatever level of the corporate chain would benefit the creditor indirectly. Alternatively, the lender could agree to lend to a lower-tier entity but seek personal guarantees by higher-tier shareholders to address the risk of shareholder opportunism. ${ }^{67}$

However, this approach may not be feasible or desirable. For example, the ultimate controlling shareholder with the power to allocate its SRL may not want to expose its personal assets in the event the new venture fails. It may prefer to have the lending occur at a lower level so that it can benefit from limited liability.

\section{b. $\quad$ Contract provisions and loan covenants}

Major loan contracts with companies are frequently intensively negotiated. Lenders seek company agreement to clauses limiting creditor risk. A frequently-included covenant of relevance to SRL is a disposal of assets covenant which is "intended to prevent asset-stripping". 68

These covenants, however, may only address and bind the company. A contract between the lender and the company normally does not bind shareholders. A successful SRL, however, can diminish corporate assets without any action by the borrower (the company) because it only requires a unilateral act by a shareholder.

Some creditors with negotiating leverage could seek other forms of protection through a variety of creative techniques. Loan contracts frequently define events of default that give lenders particular rights. Typically, the lender is able to accelerate the loan (require full payment of the entire amount) upon the occurrence of an event of default. Some lenders to companies could, for example, seek to include an acceleration clause triggered by a shareholder ISDS claim or other event related to ISDS. ${ }^{69}$

Restrictive covenants in loan contracts can raise potential problems. For example, if the creditors are numerous bondholders, the process of obtaining bondholder consent to the relaxation of covenants - which may be in creditors' interests in light of the circumstances at the time - may be expensive and timeconsuming; it could for example require the convening of a special meeting. ${ }^{70}$

\section{c. $\quad$ Expanded use of secured credit}

For creditors with sufficient bargaining power, it may be possible to take proprietary security interests over company assets. A lender to a company could also seek security interests from shareholders over their shares. Creditors might also need to address the possibility of claims by indirect shareholders in ISDS.

67 Upper-tier creditors may suffer exposure (with regard to the recovery) if the shareholder decides to brings the SRL at a lower tier level. Creditors of the claimant lower-tier entity (and of any intermediate entities) would come first. See Ferran, Principles of Corporate Finance Law, p. 333.

Id.

An acceleration clause triggered by a shareholder ISDS claim would protect the individual lender by allowing it to take immediate action to recoup its loan. However, it would create significant uncertainty about corporate financing: (i) the triggering event for acceleration would be outside of the company's control; and (ii) a shareholder ISDS claim could immediately trigger serious harm to the company's finances (over and above any injury suffered at the hands of the government). Potential ISDS claimant shareholders could also have considerable leverage over other stakeholders in the company.

See Ferran, p. 330. 
Increased use by dominant creditors of secured credit to respond to risks posed by SRL would likely shift additional risk to the unsecured creditors of the company. It may thus affect the terms and cost to the company for such inputs. ${ }^{71}$ Unsecured creditors may also incur greater costs to monitor the company's financial health which may also affect the terms and cost of credit. ${ }^{72}$

\section{d. Rely on ISDS arbitrators taking account of creditor interests in shareholder claim cases}

Creditors could rely on ISDS arbitrators recognising their priority. However, creditors may have reservations about the effectiveness of their protection in this context. Scholars have suggested that many of the powers of a bankruptcy court would be required to effectively determine whether a shareholder (or its personal creditor) should recover in the face of creditor priority:

With weak entity shielding, [the] right [of a personal creditor of shareholder] to enforce a claim on firm assets is contingent on whether sufficient firm assets will remain to pay firm creditors in full. To determine, then, whether a personal creditor [of a shareholder] should be permitted to seize firm assets, a court must accurately assess the ratio between firm assets and debts. Typically, this will require the court to exercise the broad powers associated with a bankruptcy system: the powers to stay division of firm assets and determine their aggregate value, simultaneously evaluate the validity and worth of the claims of multiple creditors, and oversee ongoing firm operations during the pendency of proceedings. ${ }^{73}$

ISDS arbitrators do not have these bankruptcy court powers. Because the company is typically not a party in an ISDS claim for reflective loss, the tribunal would not have any jurisdiction over it. With the company continuing to try to carry on its business and deal with its assets, the ability of arbitrators effectively to sift through the various claims may be in doubt. Even information about company finances and credit exposure may be difficult to obtain, particularly if the company is opposed to the claim. Only publicly available information about the largest creditors, such as bondholders, may be available.

Creditors are also rarely represented in ISDS cases involving SRL. Creditor interests will likely only be represented by the government which may argue that the claimant shareholder's recovery should be reduced because creditors have suffered some of the reflective loss. Creditors may feel that the government is a less than ideal advocate for their interests. ${ }^{74}$

$71 \quad$ See Ferran, p. 349 ("unsecured creditors may demand higher interest to compensate them for the risk of being postponed to the secured debt in the event of the borrowing company's insolvency").

Id. ("'the existence of security raises the expected cost of default for unsecured creditors by reducing the available asset pool and thus creates incentives for these parties to monitor more extensively"'), quoting A. Schwartz, Security Interests and Bankruptcy Priorities: A Review of Current Theories, 10 J. Legal Studies 1 (1981).

Henry Hansmann, Reinier Kraakman \& Richard Squire, Law and the Rise of the Firm, 119 Harv. L. Rev. 1333, 1352-53 (Mar. 2006).

The issue of damages will often arise only if the tribunal has already found that the government caused the injury to the company. The tribunal may hesitate to reduce shareholder recovery for the benefit of the government on the basis of creditor injury. 
Some larger institutional creditors may rely on shareholder reputational interests and commercial considerations. Because SRL are generally barred in advanced systems of national law, use of a SRL in ISDS to obtain a preference over creditors could be perceived as opportunistic behaviour that could affect the ability of the relevant beneficial owner to return to the credit markets in the future. Some covered shareholders with the legal ability to engage in opportunistic behaviour in ISDS may choose not to do so in light of these commercial considerations.

\section{f. $\quad$ Bring ISDS claims for reflective loss}

As noted in the Preliminary Framework, creditors may respond to the availability of SRL in ISDS by seeking to bring their own claims for reflective loss. This would further disaggregate the company loss and lead to a larger number of arbitration claims arising out of the same injury. The ratio of legal costs to recovery would likely rise. ${ }^{75}$

\section{g. Increase the price and/or decrease the availability of credit for foreign investment}

Creditors can also react to increased risk or uncertainty about the applicable rules by changing the terms on which they make credit available to the company. They can raise the price of credit or choose to lend elsewhere. Decisions in this area are affected by creditor awareness of the issues. Less sophisticated creditors, with little awareness of ISDS, may fail to adjust their terms and incur losses. ${ }^{76}$

75 No view is expressed about the likelihood of success of such claims at any stage.

76 In addition to creditors, current and potential Category II and III shareholders - who rely primarily or exclusively on company remedies - will also likely respond to the new rules on SRL in ISDS once they become better known. These effects are not considered here. As a preliminary matter, it would appear that these constituencies may, like creditors, seek to protect themselves through contract provisions or price adjustments. Alternative investments (other than in companies) may also become more attractive. These effects may depend in part on the extent to which the differential treatment of foreign and domestic shareholders is viewed as legitimate by the latter. 


\section{F. CONCLUSION}

The Preliminary Framework primarily addressed policy analysis in the specific litigation context of SRL. In that context, domestic courts and commentators have focused on the impact of SRL on fairness and efficiency with respect to defendants, creditors and others. This background paper places the rules on SRL in a broader context. Consideration of the broader corporate law functions and purposes at issue, together with the benefits of SRL for certain shareholders and the impact of SRL on respondent governments, may help governments decide about the appropriate trade-offs between different interests in formulating their policies.

Corporate law analysis may also be useful in evaluating ISDS cases. For example, the Preliminary Framework noted that ISDS arbitrators have used creative remedies such as share purchases to address certain concerns generated by SRL: in addition to paying damages, the respondent government is compelled or given the opportunity to acquire the claimant's shares for their residual value. From a corporate law perspective, a share purchase remedy converts problematic "asset stripping" by a SRL into a sale of shares from an existing shareholder to a new one. Under traditional corporate law rules, such a sale has little impact on the corporation's finances. Corporate law analysis may thus suggest that arbitrators may seek to resolve corporate law issues raised by SRL through share purchases. As noted in the Preliminary Framework, however, share purchase remedies raise a number of issues for governments including (i) their legitimacy insofar as they go beyond compensation for the injury caused; (ii) the risk of substantial additional costs to pay for the residual value of the shares; and (iii) the risk that the practical importance of the company valuation by the arbitrators will exceed that of the evaluation of damages.

As for many other issues, the practical impact of the approach to shareholder claims in ISDS will depend on a variety of other factors. For example, these may include whether investment law provides (or is perceived to provide) a form of exceptional protection that will only rarely come into play or whether it is seen as having a broader role. It may also depend on the degree to which ISDS further expands into relations between major capital exporting countries with sophisticated capital markets and whether SRL are available under treaties between those countries. 



\title{
OECD Working Papers on International Investment
}

\author{
http://www.oecd.org/daf/inv/investment-policy/working-papers.htm
}

2013

2013/4 Temporal validity of international investment agreements: a large sample survey of treaty provisions

2013/3 Investment treaties as corporate law: Shareholder claims and issues of consistency

2013/2 Lessons from Investment Policy Reform in Korea

2013/1 China Investment Policy: an Update

2012

2012/3 Investor-state dispute settlement: A scoping paper for the investment policy community

2012/2 Dispute settlement provisions in international investment agreements: A large sample survey

2012/1 Corporate greenhouse gas emission reporting: A stocktaking of government schemes

2011

2011/2 Defining and measuring green FDI: An exploratory review of existing work and evidence

2011/1 Environmental concerns in international investment agreements: a survey

2010

2010/3 OECD's FDI Restrictiveness Index: 2010 Update

2010/2 Foreign state immunity and foreign government controlled investors

2010/1 Intellectual property rights in international investment agreements

2006

2006/4 OECD's FDI regulatory restrictiveness index: Revision and extension to more economies

2006/3 Interpretation of the Umbrella Clause in Investment Agreements

2006/2 Investor-State Dispute Settlement in Infrastructure Projects

2006/1 Improving the System of Investor-State Dispute Settlement: An Overview

2005

2005/3 Corporate Responsibility Practices of Emerging Market Companies - A Fact-Finding Study

2005/2 Multilateral Influences on the OECD Guidelines for Multinational Enterprises

2005/1 Transparency and Third Party Participation in Investor-State Dispute Settlement Procedures

2004

2004/6 Mobilising Investment for Development: Role of ODA - The 1993-2003 Experience in Vietnam

2004/5 ODA and Investment for Development: What Guidance can be drawn from Investment Climate Scoreboards?

2004/4 Indirect Expropriation and the Right to Regulate in International Investment Law 
2004/3 Fair and Equitable Treatment Standard in International Investment Law

2004/2 Most-Favoured-Nation Treatment in International Investment Law

2004/1 Relationships between International Investment Agreements

2003

2003/2 Business Approaches to Combating Corrupt Practices

2003/1 Incentives-based Competition for Foreign Direct Investment: The Case of Brazil

2002

2002/2 Managing Working Conditions in the Supply Chain: A Fact-Finding Study of Corporate Practices

2002/1 Multinational Enterprises in Situations of Violent Conflict and Widespread Human Rights Abuses

2001

2001/6 Codes of Corporate Conduct: Expanded review of their contents

2001/5 The OECD Guidelines for Multinational Enterprises and other corporate responsibility instruments

2001/4 Public policy and voluntary initiatives: What roles have governments played?

2001/3 Making codes of corporate conduct work: Management control systems and corporate responsibility

2001/2 Corporate Responsibility: Results of a fact-finding mission on private initiatives

2001/1 Private Initiatives for Corporate Responsibility: An Analysis

2000

2000/5 Recent trends, policies and challenges in South East European countries

2000/4 Main determinants and impacts of FDI on China's economy

2000/3 Lithuania: Foreign Direct Investment Impact and Policy Analysis

2000/2 Investment Patterns in a Longer-Term Perspective

2000/1 Bribery and the business sector: Managing the relationship

1999

1999/3 Rules for the Global Economy: Synergies between Voluntary and Binding Approaches

1999/2 Deciphering Codes of Corporate Conduct: A Review of their Contents

1999/1 Southeast Asia: the Role of FDI Policies in Development

1998

1998/1 Survey of OECD work on international investment 